\title{
COMPARATIVE INVESTIGATION OF KNOWLEDGE OF WILD EDIBLE MUSHROOMS IN VARNA REGION WITH OTHER FOREIGN GEOGRAPHIC ZONES
}

\author{
Tsonka Dimitrova ${ }^{1}$, Petko Marinov ${ }^{2}$, Galina Yaneva ${ }^{1}$, Dobri Ivanov ${ }^{1}$ \\ 1) Department Biology, Faculty Pharmacy, Medical University, Varna, Bulgaria \\ 2) Department Pharmacology, Toxicology and Pharmacotherapy, Faculty Phar- \\ macy, Medical University, Varna, Bulgaria.
}

\begin{abstract}
Purpose: The interest in evaluation of real knowledge of wild edible mushrooms at individual and population level increases mainly in developing countries. The purpose of our inquiry study was to assess the level of knowledge and awareness of the wild mushrooms in a random sample from the population of Varna region in Bulgaria.

Material/Methods: We performed an anonymous questionnaire investigation of 200 adult individuals, 100 males and 100 females, from Varna region, including 17 potential opinions from their personal knowledge of wild edible mushroom usage. Statistical data processing was performed using descriptive methods, variation and correlation analyses.

Results: Most respondents acquired their knowledge of wild edible mushrooms from their relatives. From all 200 persons investigated 78 respondents were not capable of recognizing at least one wild edible mushroom at all. More respondents trusted other people, who have very good experience with preparation of wild mushrooms, thus relying on differentiation of a mushroom poison. Their awareness was associated with their capacity to properly recognize wild mushrooms as well as their long-term practice to recognize toxic mushrooms. Just a minority of respondents shared that wild mushrooms in their vicinity could be a problem and had a slight idea of mycotherapy. Only two females had heard about training for wild mushroom recognition. There were statistically significant correlation dependences between respondent's awareness of wild edible mushrooms, on one hand, and individual sex status, educational level and main residence, on the other hand.

Conclusion: Our study identified two most recognized wild edible mushroom species in Varna region, edible boletus (Boletus edulis Bull) and parasol mushroom (Macrolepiota procera S. F. Gray). Most respondents acquired their knowledge of wild edible mushrooms from relatives. A problem-oriented training of the population on this topic should be performed to improve awareness of common mushroom features and avoid mushroom poisoning.
\end{abstract}

Keywords: wild edible mushrooms, knowledge, inquiry, Varna region

\section{INTRODUCTION}

Recently, there is rising interest in the assessment of the real knowledge of wild edible mushrooms at individual and population level mainly in developing countries.

There are people, who consider as poisonous all mushrooms and they do not include them in their diet. This fact indicates that knowledge and interest depends on traditions of consumption $[1,2]$. The local knowledge of wild edible mushrooms and their cultural importance are evaluated and compared using qualitative and quantitative methods [3]. Ethnomycology studies provide in depth local knowledge on edible mushrooms for a defined region [4].

The review of publications about the biodiversity of 275 native medicinal species traditionally used in South Tyrol, Northern Italy, Southern Alps, identifies only three mushrooms [5]. Two species, Fomitopsis betulina and Fomitopsis officinalis, belong to the family of Fomitopsidaceae while a third one, Auricularia auricula-judae refers to the family of Auriculariaceae. Although the ethnobotanical richness of this region is among the highest in Italy and throughout the Alps, traditional knowledge of wild mushrooms is heavily eroded.

The transformations of local environmental knowledge concerning wild mushrooms in the Upper Sangone Valley, Western Italian Alps, Piedmont, North Western Italy, during the past 40 years are analyzed [6]. The re-arrangement of a more domestic and more 'globalized' mushroom knowledge system is possibly inspired by new urban residents, who start to populate the valley at the end of the seventies of the last century, when the original inhabitants abandon their homes for the urban centres of the Piedmontese plain.

The dependence between knowledge of mushrooms and the place of origin, admitted by 580 students, as well as frequency of participation in mushrooming, preferred sources of information about mushrooms and self-competence in discriminating the mushrooms in three university schools in Poland is determined [7]. Residents of large cities have more often difficulties than those from villages and small towns in distinguishing the edible and toxic mushrooms. Parents are the primary source of knowledge 
on mushrooms for majority of students. Almost $20 \%$ of respondents believe that even deadly toxic species can be safely consumed after culinary preparation.

\section{MATERIALS \& METHODS}

We carried out in 2020 an anonymous inquiry study of 200 adult individuals, 100 males and 100 females, from the towns and villages of Varna region concerning their knowledge and awareness of wild edible mushrooms. The respondents expressed their own opinion concerning a total of 17 specific items about several aspects of acquisition and analysis of information of wild edible mushrooms.

Respondents and their distribution according to sex, age groups, education and main residence is presented in Table 1.

Table 1. Respondents' distribution according to sex, age groups, education and main residence

\begin{tabular}{|l|c|c|c|}
\hline Age groups/education/residence & males & females & total \\
\hline \multicolumn{3}{|c|}{ Age groups } \\
\hline 21-30 years & 14 & 15 & 29 \\
\hline $31-40$ years & 14 & 6 & 20 \\
\hline $41-50$ years & 13 & 26 & 39 \\
\hline $51-60$ years & 29 & 25 & 54 \\
\hline 61-70 years & 21 & 25 & 46 \\
\hline $71-80$ years & 9 & 3 & 12 \\
\hline & Education & 43 & 79 \\
\hline secondary & 36 & 23 & 37 \\
\hline elementary & 14 & 34 & 84 \\
\hline higher & 50 & 52 & 112 \\
\hline & Residence & 88 \\
\hline town & 60 & 48 & \\
\hline village & 40 & & \\
\hline
\end{tabular}

Statistical data processing was performed by means of descriptive methods, variation and correlation analyses (Student-Fisher's test, Fisher's exact test, Pearson's coefficient and $\chi 2$ independent test). Statistical significance was considered at a level of $\mathrm{p}<0.05$.

\section{RESULTS}

Our results are shown in five tables and one figure.

Respondents' distribution according to sex and knowledge of wild edible mushroom acquisition is demonstrated in Table 2.

Table 2. Respondents' distribution according to sex and knowledge of wild edible mushroom acquisition

\begin{tabular}{|l|c|c|c|c|c|c|}
\hline \multirow{2}{*}{ Knowledge acquisition } & \multicolumn{2}{|c|}{ males } & \multicolumn{2}{c|}{ females } & \multicolumn{2}{c|}{ total } \\
\cline { 2 - 7 } & yes & no & yes & no & yes & no \\
\hline from parents & 3 & 97 & 7 & 93 & 10 & 190 \\
\hline from close people & 5 & 95 & 5 & 95 & 10 & 190 \\
\hline from Internet & 16 & 84 & 5 & 95 & 21 & 179 \\
\hline from books & 25 & 75 & 13 & 87 & 38 & 162 \\
\hline from relatives & 55 & 45 & 46 & 54 & 101 & 99 \\
\hline from acquaintances & 1 & 99 & 2 & 98 & 3 & 197 \\
\hline
\end{tabular}

It is noteworthy that all respondents, incl. males and females in separate groupd, acquire their knowledge of wild edible mushrooms predominantly from their relatives, while books and Internet sites occupy the second and third place as reliable information sources, respectively. The family plays an insignificant role in the process of this specific knowledge acquisition.

In Table 3, Latin denominations of 13 wild edible mushrooms, most recognized by male and female respondents, are listed. 
Table 3. Latin denominations of 13 most recognized wild edible mushrooms

\begin{tabular}{|l|c|c|c|c|c|c|}
\hline \multirow{2}{*}{ Latin mushroom denomination } & \multicolumn{2}{|c|}{ males $(\mathrm{n}=64)$} & \multicolumn{2}{|c|}{ females $(\mathrm{n}=58)$} & \multicolumn{2}{c|}{ total $(\mathrm{n}=122)$} \\
\cline { 2 - 7 } & $\mathrm{n}$ & $\%$ & $\mathrm{n}$ & $\%$ & $\mathrm{n}$ & $\%$ \\
\hline Boletus edulis Bull & 63 & 98.44 & 51 & 87.93 & 114 & 93.44 \\
\hline Macrolepiota procera S. F. Gray & 60 & 93.75 & 47 & 81.03 & 107 & 87.70 \\
\hline Cantharellus cibarius Fr. & 51 & 79.69 & 41 & 70.69 & 92 & 75.41 \\
\hline Marasimus oreades & 43 & 67.19 & 41 & 70.69 & 84 & 68.85 \\
\hline Armillariella mellea & 43 & 67.19 & 33 & 56.90 & 76 & 62.29 \\
\hline Amanita caesarea & 41 & 64.06 & 34 & 58.62 & 75 & 61.47 \\
\hline Bovista nigrescens & 35 & 54.69 & 24 & 41.38 & 59 & 48.36 \\
\hline Agaricus silvaticus & 13 & 20.31 & 45 & 77.59 & 58 & 47.54 \\
\hline Suillus luteus & 35 & 54.69 & 13 & 22.41 & 48 & 39.34 \\
\hline Sarcoscypha coccinea & 26 & 40.62 & 16 & 27.59 & 42 & 34.43 \\
\hline Gomphidius glutinosus & 27 & 42.19 & 4 & 6.90 & 31 & 25.41 \\
\hline Agaricus campester & 17 & 26.56 & 7 & 12.07 & 24 & 19.67 \\
\hline Pleurotus ostreatus & 16 & 25.00 & 1 & 1.72 & 17 & 13.93 \\
\hline
\end{tabular}

The difference between male and female respondents concerning the number of persons who recognize the wild edible forest mushroom Agaricus silvaticus is statistically significant $(t=4.485 ; \mathrm{p}<0.001)$.

More respondents (113 versus 87 ) confide in people who have prepared wild mushrooms, mainly males $(65$ versus 35 females). Only 50 respondents share that wild mushrooms in the local environment are considered as a threat mainly by females (32 versus 18 ). More respondents (114 versus 86 ), predominantly males (62 versus 62 ), can differentiate a mushroom poisoning. Most respondents (130 versus 70) are aware of cases with mushroom intoxications in their close area. The mean numbers of known lethal cases, reported by a respondent are similar among males $(2.35 \pm 0.205)$ and females $(2.15 \pm 0.218)$. More respondents (109 versus 91) are self-confident concerning their capacity to properly recognize wild mushrooms, mainly males (62 versus 47). Only two female respondents have ever heard about any form of training for wild mushroom recognition. On the other hand, much more respondents (139 versus 61) have already seen toxic mushrooms (85 males and 54 females). The minority of respondents (56 towards 144) has not an idea of mycotherapy (31 males and 25 females only).
We establish a series of statistically significant correlation dependences between respondent's awareness of wild edible mushrooms, on one hand, and individual sex belonging, in favour of males (Pearson's coefficient $\chi^{2}=4.537 ; \mathrm{p}=0.033$; Fisher's exact test $\mathrm{p}=0.023$ ), educational level in favour of elementary education (Pearson's coefficient $\left.\chi^{2}=30.032 ; \mathrm{p}<0.001\right)$ and main residence in favour of villages (Pearson's coefficient $\chi^{2}=23.761 ; \mathrm{p}<0.001$; Fisher's exact test $\mathrm{p}<0.001)$, on the other hand. There is however, a statistically insignificant correlation between knowledge of mycotherapy as a scientific discipline and educational level (Pearson's coefficient $\chi^{2}=2.048$; $\mathrm{p}=0.359$ ).

There are 122 respondents, 64 males and 58 females who report that they recognize at least one wild edible mushroom available in the region of the Northern Black Sea coast in Bulgaria. Males well recognize a total of 24 and females are aware of a total of 26 different wild edible mushroom species. The rest 78 respondents, 36 males and 42 females, claim that they are not capable of recognizing at least one wild edible mushroom at all.

Respondents' distributions according to their capacity to recognize wild edible mushroom expressed with positive or negative answers to this specific item and depending on age groups, education and main residence, are systematized in Table 4, ongoing through Table 6.

Table 4. Respondents' distribution depending on positive or negative answers concerning wild edible mushroom recognition according to sex and age groups

\begin{tabular}{|l|c|c|c|c|c|c|}
\hline \multirow{2}{*}{ Age groups } & \multicolumn{2}{|c|}{ males } & \multicolumn{2}{c|}{ females } & \multicolumn{2}{c|}{ total } \\
\cline { 2 - 7 } & positive & negative & positive & negative & positive & negative \\
\hline 21-30 years & 9 & 5 & 3 & 12 & 12 & 17 \\
\hline 31-40 years & 8 & 6 & 4 & 2 & 12 & 8 \\
\hline 41-50 years & 8 & 5 & 19 & 7 & 27 & 12 \\
\hline 51-60 years & 23 & 6 & 15 & 10 & 38 & 16 \\
\hline 61-70 years & 12 & 9 & 16 & 9 & 28 & 18 \\
\hline
\end{tabular}




\begin{tabular}{|l|c|c|c|c|c|c|}
\hline $71-80$ years & 4 & 5 & 1 & 2 & 5 & 7 \\
\hline total & 64 & 36 & 58 & 42 & 122 & 78 \\
\hline
\end{tabular}

There are no statistically significant differences concerning the relative shares of positive and negative answers because the small respondents' sample in single age groups.

According to data listed in Table 5, males with higher education present a statistically significantly greater

number and relative share of negative answers $(t=3.387$; $\mathrm{p}<0.01)$. The number and relative share of negative answers of all respondents with higher and elementary education are statistically and significantly greater, too $(t=3.095$; $\mathrm{p}<0.01$ and $t=3.103 ; \mathrm{p}<0.01$, respectively).

Table 5. Respondents' distribution depending on positive or negative answers concerning wild edible mushroom recognition according to sex and educational level

\begin{tabular}{|l|c|c|c|c|c|c|}
\hline \multirow{2}{*}{ Age groups } & \multicolumn{2}{|c|}{ males } & \multicolumn{2}{c|}{ females } & \multicolumn{2}{c|}{ total } \\
\cline { 2 - 7 } & positive & negative & positive & negative & positive & negative \\
\hline secondary & 28 & 8 & 23 & 20 & 51 & 28 \\
\hline elementary & 14 & 0 & 21 & 2 & 35 & 2 \\
\hline higher & 22 & 28 & 14 & 20 & 36 & 48 \\
\hline total & 64 & 36 & 58 & 42 & 122 & 78 \\
\hline
\end{tabular}

Table 6. Respondents' distribution depending on positive or negative answers concerning wild edible mushroom recognition according to sex and main residence

\begin{tabular}{|l|c|c|c|c|c|c|}
\hline \multirow{2}{*}{ Age groups } & \multicolumn{2}{|c|}{ males } & \multicolumn{2}{c|}{ females } & \multicolumn{2}{c|}{ total } \\
\cline { 2 - 7 } & positive & negative & positive & negative & positive & negative \\
\hline town & 29 & 31 & 25 & 27 & 54 & 58 \\
\hline village & 35 & 5 & 33 & 15 & 68 & 20 \\
\hline total & 64 & 36 & 58 & 42 & 122 & 78 \\
\hline
\end{tabular}

The number and relative share of males from towns and villages with negative answers are statistically and significantly greater than those of respondents with positive answers $(t=3.663 ; \mathrm{p}<0.001$ and $t=2.317 ; \mathrm{p}<0.05$, respectively). The number and relative share of all respondents from towns with negative answers are statistically significantly greater $(t=3.396 ; \mathrm{p}<0.01)$. The number and relative share of all respondents from villages with positive answers are statistically and significantly greater $(t=2.624 ; \mathrm{p}<0.02)$.
Fig. 1 compares the number of males and females according to the number of most common mushrooms recognized by single respondent. There are considerable differences between both sexes. It is a demonstrative fact that six different mushrooms are recognized by 18 females $(31.03 \%)$, whereas by only seven males $(10.94 \%)$, while seven different mushrooms are recognized by nine men $(14.05 \%)$, whereas by only one woman $(1.72 \%$ of all cases).

Fig. 1. Respondents' distribution according to sex and number of recognized mushrooms

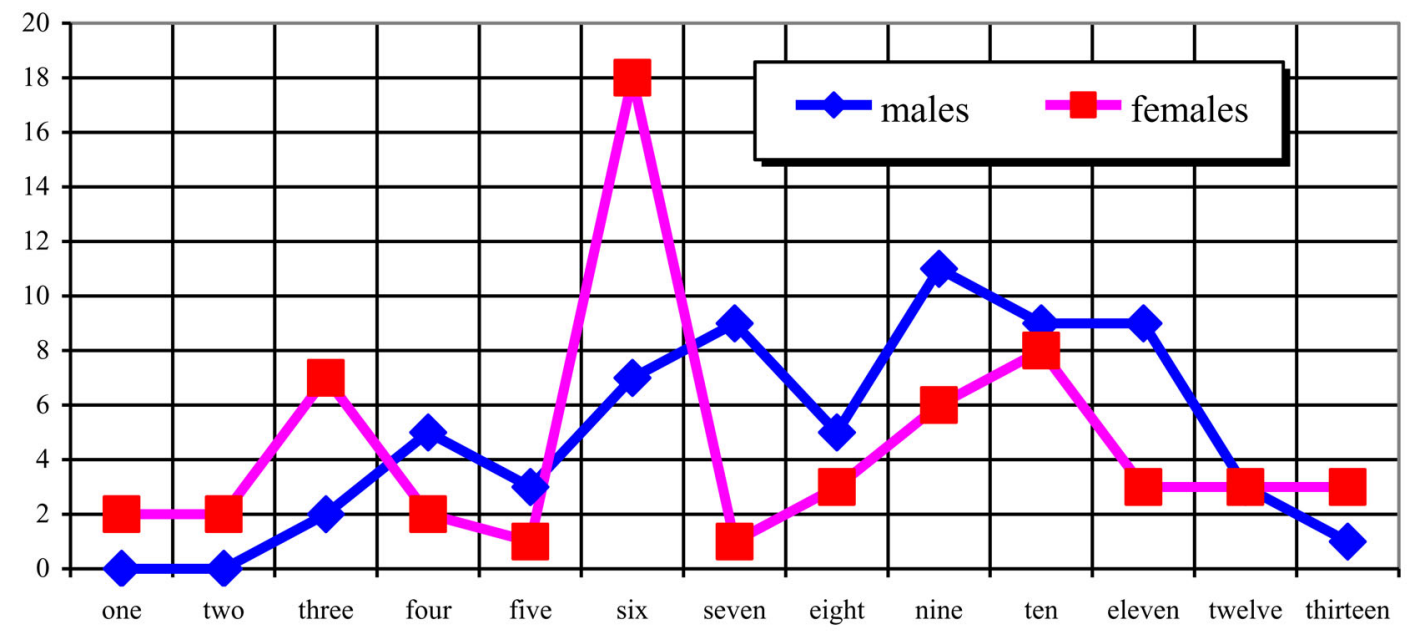




\section{DISCUSSION}

Our initial inquiry data obtained are indeed promising. Respondents' knowledge of wild edible mushrooms available is relatively sufficient.

Positive answers concerning the recognition of wild edible mushrooms prevail among the respondents with secondary education, whereas negative answers are most common among those with higher education.

Knowledge of wild mushrooms among 125 students of tourism and recreation in Poland is tested by means of questionnaire [8]. Parents are primary source of such knowledge for $84 \%$ of mushrooms pickers. Up to $70 \%$ of respondents consider at least one irrational method useful to distinguish edible from poisonous mushrooms. Fifty-three per cent of students are aware of only one deadly toxic mushroom growing in Poland.

Within an ethnomycological study using interviews among Nahua wild mushroom pickers in San Isidro Buensuceso in Central Mexico, it is established that these people classify fungi primarily based on their use, where they grow, and by humoral patterns [10]. Detailed knowledge of mushrooms in this Nahua community is identified. The criteria used for recognition of species are very reliable, since these mushroom pickers apply organoleptic, ecological, phenological and morphological characteristics.

During a four-year period, the traditional ethnomycological knowledge of wild edible mushrooms by Maya inhabitants of the municipality of San Juan Sacatepéquez in Kaqchikel area in the central highlands of Guatemala, is studied using focused interviews [11]. There is a serious knowledge about edible and inedible species that is transmitted mainly within the family nucleus. Despite the traditional knowledge erosion, mushrooms continue to be culturally and economically important for these communities in Guatemala.

The number of wild edible mushrooms recognized by respondents in our investigation is relatively great.

The ethnomycological investigation of 160 inhabitants in six different ethnic communities from the Tshopo province in the Democratic Republic of the Congo demonstrates that traditional knowledge of 73 species of wild edible mushrooms differs between ethnic groups [9].

The indigenous Yi ethnomycological knowledge in four communities in Nanhua County, China, is investigated using both interviews and harvesting observations [12]. Around 90 unique, named folk species, are reported or observed, with 54 species, reported multiple times. Local mushroom names encode information about local ecology, species morphology, and abstract metaphorical ideas. Directly observing mushroom harvests captures more detailed knowledge than recall-based interviews including a greater number of species and a more nuanced, multi-leveled taxonomic system.

In a ethnobotanical study using interviews and field observations, traditional knowledge of wild edible mushrooms of 121 permanent residents in six localities of the Bamenda Highlands of Cameroon, 76 males and 45 females, aged up to 50 years, is assessed [13]. Information gathered includes local name of the mushroom, partially used, and informant's perception on species availability. Three of six mushroom species of family Trichomataceae, Termitomyces clypeatus (6.4\%), Termitomyces letestui (4.1\%) and Termitomyces $\mathrm{sp}$. (4\%) are more commonly recorded, while the rest three species, such as Termitomyces ourantiacus of family Lyophyllaceae, Lentinus squarrosulus of family Polyporaceae and Pleurotus pulmonarius of family Pleurotaceae, are seldomly mentioned. Most respondents $(62.5 \%)$ consider current mushroom availability less than before, $14.0 \%$ of these individuals believe that it is bigger, while $23.5 \%$ do not observe any change.

During ethnobiological tours, semi-structured interviews with 37 individuals from different communities in the municipality of Villa Guerrero in Northern Jalisco, Mexico, about wild edible mushrooms are carried out to assess traditional nomenclature, classification and knowledge of mushrooms [14]. There are records of 37 mushroom species. Cultural knowledge of mushroom phenology and ecology is registered in addition to data highlighting the cultural exchange between these communities. There is a loss in the knowledge of mushrooms resulting from social changes.

Ethnic knowledge on 51 wild edible mushrooms (in 23 genera) pertaining to their habitats, substrates, mutualistic association, extent of availability and extent of edibility in the Western Ghats region of India is investigated [15]. The most preferred mushrooms are Astraeus hygrometricus, Clitocybe infundibuliformis, Fistulina hepatica, Lentinus sajor-caju, Scleroderma citrinum, Pleurotus (five species) and Termitomyces (18 species). The importance of documentation of traditional knowledge of these wild edible mushrooms is outlined.

Interviews dealing with local systematics and free listings of wild edible and toxic mushrooms are performed in 133 Tsotsil people from seven communities in the highlands of Chiapas, Mexico [2]. The differences in their knowledge relating to different sociodemographic subsets such as gender, education and occupation are examined. Twenty-five edible and 15 toxic taxa are mentioned, whereas only $62 \%$ of the respondents name toxic mushrooms, mainly Amanita muscaria, Suillellus luridus and Russula emetica. There are significant differences between men and women concerning the number of times toxic ethnotaxa are mentioned. Education and occupation are most important for people to know more or less mushroom species.

Between 2009 and 2014, 116 non-structured and semi-structured interviews are performed to analyze the traditional knowledge of wild mushrooms in communities of the Mixteca Alta, Southeastern Mexico, focusing on the regional nomenclature and classification of the identified species, their edibility, toxicity, habitat, traditional recipes and differentiation criteria between toxic and edible species as well as on mechanisms of knowledge transmission [16]. There exists a complex and accurate knowledge of Mixtecs related with the nomenclature, classification, ecology and gastronomy of wild edible mushrooms. A relation between natural vegetation cover, lower soil erosion and higher economic marginalization and richness, on one 
hand, and knowledge of wild mushrooms, on the other hand, is established in these communities.

By means of semi-structured interviews, focus group discussions, participant's observations and walk-in-thewoods methods, 15 edible out of a total of 20 ethnomycologically important wild mushroom species belonging to ten genera and six families are identified in Menge District, Asossa Zone, Benshangul Gumuz Region, Ethiopia [17]. Nine species of Lyophyllaceae family and seven species of Agaricaceae family prevail. There are statistically significant differences in terms of the mean number of wild edible mushrooms between the different groups of respondents $(\mathrm{p}<0.05)$.

Semi-structured interviews, walks in Nothofagaceae forests and participant's observations are carried out by an ethnobiological approach among rural inhabitants of five Mapuche communities from North Western Patagonia, Argentina in order to evaluate their traditional mycological knowledge [18]. Indigenous morels such as Morchella aff. tridentina and Morchella aff. septimelata have the greatest cultural importance at a regional level. Regional knowledge about wild edible mushrooms reflects important features of Mapuche tradition and the process of change in response to complex and dynamic socioeconomic and ecological contexts.

A greater part of the respondents in our study have already seen toxic mushrooms.

Between 2010 and 2012, semi-structured interviews of 197 inhabitants from seven locations in Urique, Bocoyna and Cusarare area within two municipalities of the Sierra Tarahumara, Chihuahua, Northern Mexico, concerning knowledge of wild edible mushrooms are performed [19]. Criteria for differentiating 22 local edible mushroom and two toxic species as well as peculiarities of local nomenclature, appreciation of taste and traditional teaching are assessed. Preference for the following five species is reported: Amanita rubescens, Agaricus campestris, Ustilago maydis, Hypomyces lactifluorum and Amanita caesarea complex.
During 13 ethnomycological expeditions and seven requests in two communities residing in La Malintzi National Park, Tlaxcala, Mexico, a total of 178 wild mushroom species is recognized as non-edible by locals inhabitants, which corresponds to 103 species belonging to 45 genera [3]. Non-edible species are seen as a cosmogonic counterpart ('twins') of the edible species that they resemble. A total of 101 specific recognition criteria are obtained useful only when comparing paired edible versus non-edible species.

The sources of knowledge about wild mushrooms for food and medicine in three rural areas, Småland in South Sweden, Roztochya in Western Ukraine and Kortkeros in North West Russian Federation, are studied by means of a total of 205 in-depth semi-structured interviews [20]. In Roztochya, 15 species of nine families, in Kortkeros, 16 species of eight families, but in Småland - only five species of three families are collected. The chanterelle (Cantharellus cibarius Fr.) and funnel chanterelle (Craterellus tubaeformis (Fr.) are most popular mushrooms in Småland. Two Boletus spp., Polyporus umbellatus (Pers.) and Grifola frondosa (Dicks.) are most harvested in Roztochya, and Lactarius spp. is most oftenly collected in Kortkeros.

\section{CONCLUSION}

Our investigation identifies two most-recognized wild edible mushroom species in Varna region, edible boletus (Boletus edulis Bull) and parasol mushroom (Macrolepiota procera S. F. Gray). Some 122 respondents recognize at least one wild edible mushroom. They acquire their knowledge of such mushrooms predominantly from relatives. These results could serve as a basis for a more comprehensive evaluation of individual awareness and knowledge of wild edible mushrooms in Bulgaria. A problem-oriented training of the population on this topic should be performed in order to improve awareness of common mushroom features to avoid mushroom poisoning.

\section{REFERENCES:}

1. Hansepi P, Teron R. Eschewing poisons: an ingenious wisdom of foraging macrofungi by Karbi ethnic group in North East India. Curr Sci. 2018; 115(7):1328-1333. [Crossref]

2. Ruan-Soto F. Sociodemographic differences in the cultural significance of edible and toxic mushrooms among Tsotsil towns in the Highlands of Chiapas, Mexico. J Ethnobiol Ethnomed. 2018 May 3;14(1):32. [PubMed]

3. Ramírez-Terrazo A, Adriana Montoya E, Garibay-Orijel R, Caballero-Nieto J, Kong-Luz A, MéndezEspinoza C. Breaking the paradigms of residual categories and neglectable importance of non-used resources: the "vital" traditional knowledge of nonedible mushrooms and their substantive cultural significance. J Ethnobiol Ethnomed. 2021 Apr 21;17(1):28. [PubMed]

4. Comandini O, Rinaldi AC. Ethnomycology in Europe: The past, the present, and the future. In: Mushrooms, humans and nature in a changing world. J. Perez Moreno, A. Guerin Laguette, R. Flores Arzu, F. Q. Yu, eds. Cham, Switzerland: Springer International Publishing, 2020; 341-364.

5. Petelka J, Plagg B, Saumel I,
Zerbe S. Traditional medicinal plants in South Tyrol (northern Italy, southern Alps): biodiversity and use. $J$ Ethnobiol Ethnomed. 2020 Nov 26;16(1):74. [PubMed]

6. Fontefrancesco MF, Pieroni A. Renegotiating situativity: transformations of local herbal knowledge in a Western Alpine valley during the past 40 years. J Ethnobiol Ethnomed. 2020 Oct 1;16(1):58. [PubMed]

7. Chwaluk P, Parnicki F, CisoñApanasewicz U, Potok H, Kieityka A. Czynniki warunkujace wiedze studentyw o grzybach dziko rosnacych. Przegl Lek. 2012;69(8):455-458. 
8. Chwaluk P, Parnicki F. Wiedza studentyw turystyki i rekreacji Akademii Wychowania Fizycznego na temat grzybyw dziko rosnacych. Przegl Lek. 2011;68(8):436-439.

9. Milenge Kamalebo H, Nshimba Seya Wa Malale H, Masumbuko Ndabaga C, Degreef J, De Kesel A. Uses and importance of wild fungi: traditional knowledge from the Tshopo province in the Democratic Republic of the Congo. J Ethnobiol Ethnomed. 2018 Feb 12;14(1):13. [PubMed]

10. Reyes-López RC, Montoya A, Kong A, Cruz-Campuzano EA, Caballero-Nieto J. Folk classification of wild mushrooms from San Isidro Buensuceso, Tlaxcala, Central Mexico. J Ethnobiol Ethnomed. 2020 Sep 14;16(1):53. [PubMed]

11. Mérida Ponce JP, Hernández Calderón MA, Comandini O, Rinaldi AC, Flores Arzú R. Ethnomycological knowledge among Kaqchikel, indigenous Maya people of Guatemalan Highlands. J Ethnobiol Ethnomed. 2019 Jul 17;15(1):36. [PubMed]

12. Brown M. Yi ethnomycology: Wild mushroom knowledge and use in Yunnan, China. J Ethnobiol. 2019
Mar;39(1):131-157. [Crossref]

13. Fongnzossie EF, Nyangono CFB, Biwole AB, Ebai PNB, Ndifongwa NB, Motove J, Dibong SD. Wild edible plants and mushrooms of the Bamenda Highlands in Cameroon: ethnobotanical assessment and potentials for enhancing food security. $J$ Ethnobiol Ethnomed. 2020 Mar 4;16(1):12. [PubMed]

14. Haro-Luna MX, Ruan-Soto F, Guzmán-Dávalos L. Traditional knowledge, uses, and perceptions of mushrooms among the Wixaritari and mestizos of Villa Guerrero, Jalisco, Mexico. IMA Fungus. 2019 Sep 16;10:16. doi: 10.1186/s43008-019-0014-6. [PubMed]

15. Karun NC, Sridhar KR. Edible wild mushrooms of the Western Ghats: Data on the ethnic knowledge. Data Brief. 2017 Jul 27;14:320-328. [PubMed]

16. Santiago FH, Moreno JP, Cázares BX, Suárez JJ, Trejo EO, de Oca GM, et al. Traditional knowledge and use of wild mushrooms by Mixtecs or Nuu savi, the people of the rain, from Southeastern Mexico. $J$ Ethnobiol Ethnomed. 2016 Sep

\section{5;12(1):35. [PubMed]}

17. Sitotaw R, Lulekal E, Abate D. Ethnomycological study of edible and medicinal mushrooms in Menge District, Asossa Zone, Benshangul Gumuz Region, Ethiopia. J Ethnobiol Ethnomed. 2020 Mar 4;16(1):11.

18. Molares S, Toledo CV, Stecher G, Barroetaveña C. Traditional mycological knowledge and processes of change in Mapuche communities from Patagonia, Argentina: A study on wild edible fungi in Nothofagaceae forests. Mycologia. 2020 Jan-Feb;112(1):9-23 [PubMed]

19. Quiñónez-Martínez M, RuanSoto F, Aguilar-Moreno IE, GarzaOcañas F, Lebgue-Keleng T, LavínMurcio PA, et al. Knowledge and use of edible mushrooms in two municipalities of the Sierra Tarahumara, Chihuahua, Mexico. J Ethnobiol Ethnomed. 2014 Sep 17;10:67. [PubMed]

20. Stryamets N, Elbakidze M, Ceuterick M, Angelstam P, Axelsson R. From economic survival to recreation: contemporary uses of wild food and medicine in rural Sweden, Ukraine and NW Russia. J Ethnobiol Ethnomed. 2015 Jun 16;11:53. [PubMed]

Please cite this article as: Dimitrova T, Marinov P, Yaneva G, Ivanov D. Comparative investigation of knowledge of wild edible mushrooms in Varna region with other foreign geographic zones. J of IMAB. 2021 Oct-Dec;27(4):41574163. DOI: https://doi.org/10.5272/jimab.2021274.4157

Received: 01/06/2021; Published online: 13/11/2021
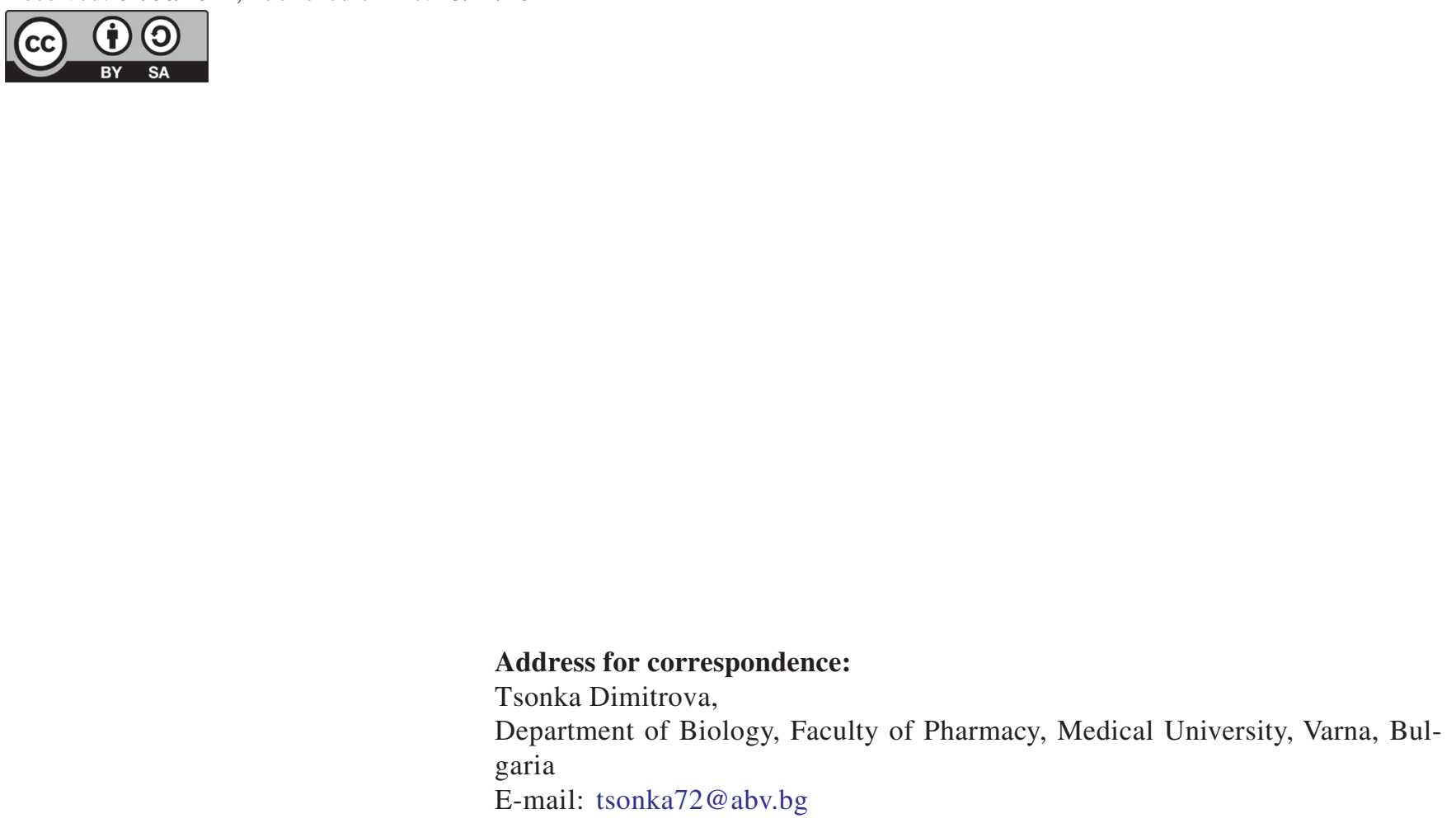